\title{
Ethymological Analysis of Horiats in Iraq Turkmen Folk Poetry
}

\author{
Zeynel Polat ${ }^{1}$ \\ ${ }^{1}$ Ishik University, Erbil, Iraq \\ Correspondence: Zeynel Polat, Ishik University, Erbil, Iraq. \\ Email: zeynel.polat@ishik.edu.iq \\ Received: July 10, 2019 \\ Accepted: August 19, 2019 \\ Online Published: September 1, 2019 \\ doi: 10.23918/ijsses.v6i1p171
}

\begin{abstract}
Horyat is a kind of poetry which is passed from one generation to the next and written and told as puns and stanzas. Although it is known with different names in different places in the world, it is called horyat among Iraqi Turkmens by functioning as a media to transfer language and culture. It is not needed to be educated to tell and write horyat. Horyat is a national gratification used to carry language and culture of people from one generation to the next. Generally, it has 4 lines and 7 syllables. There can be change with additional words called "miyan" at the beginning, in the mid or at the end of lines. The aim of it is to point the pun. Horyats are the most important type of Iraqi Turkmen oral folk literature. People who tell horyat are called "horyat çığıran" (horyat yeller), "horyat sazlıyan" (horyat player). This type of folk poetry can be found in different names in Iraq. In this research, we mentioned different variations of horyat in different cultures of Turkish speaking people and ideas of contemporary Turkmen poets and masters of horyat such as Ziyad Akkoyunlu and Ata Terzibasi. Data collection for this research was done with interviews with people who are related with horyat in the region. This poetry type that belongs to Iraqi Turkmens is shown with its function under the influence of dialects of " $v$ " and " $y$ " group; and the etymologic varieties of the word are discussed. Our primary aim is not to insist on the right word; hoyrat, horyat, koryat or xoryat etc, but to prefer the correct usage in its meaningful context and to show its regional use.
\end{abstract}

Keywords: Horyat, Hoyrat, Folk Poetry, Iraqi Turkmen Literature

\section{Introduction}

Mankind has been using words to communicate by blending it with oral artistry. Oral literature came before the written one and got the duty to transfer traditions, customs and antiquities from past to present. Iraqi Turkmens with a rooted history lived under the rule of strong states and seigniories named Buveyhis, Seljuks, Atabeys, Ilhans, Celayiris, Karakoyunlus, Akkoyunlus, Persians and Ottomans. Turks came to Iraq in 674 (54 in Muslim Calender) (Saatçi, 2007). Iraqi Turkmens saved their traditions they brought from Oghuzs by carrying them from generation to generation. A nation's language, history, literature, social and political structure, traditions, customs, beliefs and their practices are all consistent with oral products of this nation. Turkish clans sharing the same geography, language and history saved most of their traditions and customs and carried to today (Köse,2003).

\section{Definition of Horyat}

Horyat (Gre. Khoriates) is the name of a traditional Turkish quatrain form, mani, among Iraqi Turkmens especially among Kirkuki Turkmens. Horyat, a quatrain form with pun, is one of the poetical forms 
commonly used in folk literature (Ayverdi, 2008). It is mostly told in 4 lines and free style. In Çayırbayır's comprehensive Turkish dictionary, horyat is described as the name of manis which are the shortest poetical type of folk literature in South East Anatolian and Kirkuk Turks. Mani with pun (cinaslı mani) is described as the mani told by men in Sanliurfa (Çağbayır, 2007). Horyat means poor, indigent, idle. There is another use of it as koryat meaning "bad, rude, ugly". This is derived from a place named Korya in Kirkuk. But this usage belongs to nations in the area other than Turkmens. In our interviews, Turkmens are rejecting this usage because they claim that horyat is an art and told by educated people who are loyal to their culture. In the original horyat, a mood of bravery is dominating words and tune. It is common among Iraqi Turkmens especially around Kirkuk and in Kirkuk; in Anatolia especially in Şanlıurfa, Elazı $\breve{g}$, Erzurum and Kars. Horyat has a tendency to be with pun. It mostly consists of 7 syllables. In order to get attention, to make some additions and to make it easy to start horyat, there can be some words at the beginning that are called "miyan". Miyans are not convenient with the normal horyat meter. In Turkish folk literature, horyat is mostly called as "broken mani (kesik mani)". When the number of verses is increased, it is called winged horyat (kanatlı horyat) while it is called legged mani (ayaklı mani) with its number of verses. A person who performs horyat is called "horyat yeller (horyat çağıran)" while he is called "horyat crier" (sazlayan or sizlayan) if the horyat is about mourning a dead person. Horyat can be also described as Turkmen folk poetry and folk music made of this poetry with its 7 syllables and 4 lines -can be increasedstructure. In horyats, caesuras are changeable with "miyan" additions. 7-syllable horyats, the most common ones, have caesuras as $4+3,3+4,5+2$, and $2+5$. When horyats with four lines are considered, 1 st, 2nd and 4th lines are rhymed, 3rd line is free. If the number of lines are increased, 6th, 8th and 10th lines can be also rhymed. Here are some examples of horyats:

"Meyde ne var

Kim bilir meyde ne var

Namarda meydan virme

Sen at1l meydana var"

"Var dağlar

Var tepeler var dağlar

Kimini yox dağlıyıb

Kimini de var dağlar"

"Yüzdü yar

Suya endi yüzdü yar

Yurdumun dadın virmez

İster dolaş yüz diyar"

(Retold by Fazıl (Kaleli) Muhammed (Mehmet) Hidır, Horyat teller, retired teacher/Kirkuk)

\section{Different Versions of Horyat}

Horyat was called with different names among different Turkish speaking communities. Iraqi Turkmens belonging to Oghuz clan, Irani Turks, Gagauzs and some parts of Anatolia called "horyat-hoyrat, mani, türkü, aşule" while Azerbaijani Turks called it "bayati". Some other names are as the following: Turkish in Turkey: Hoyrat 
Iraqi Turkmen Turkish: Horyat, Koryat

Azerbaijani Turkish: Saligasiz

Bashkurt Turkish: İgtibarhız, arama yataya'ya tupas

Kazakh Turkish: Kolay bolsa solay

Kirghiz Turkish: Kopol, oldoksan

Uzbek Turkish: E’tibarsız pala partiş, kors

Tatar Turkish: Topas, crynaksiz

Turkmenistan Turkish: Harsal

Uygur Turkish: Parvasız kopal (Ercilasun,1991, pp.348-349)

According to Pasayev, by considering their functions, horyats are called "bayati" in Azerbaijan, "mani" in Gagavuzs, "Ashula and kushik" among Uzbeks, "horyat, ayaklı mani, kesik mani” in Turkey. (Paşayev, 1998, p.119)

In his Arabic article titled "Altun Kopru”, Tevfik Vehbi, one of the most important linguists of Iraq, wrote that horyat has the same root with "kor" in Uygur language, and the same root with "her" in some other Turkish dialect and new Iranian language. All these words mean love in plains, low, worthless, croaked and etc (cited in Sarıkaya, 2006). Since horyats are in syllabic meter, we understand that they were also told before Islamic period and affected Divan Literature after Islamic Period (Sarıkaya, 2006).

\section{Etymology and History of Horyat}

Some of the different versions of the word and meanings are these:

Horyad = hor -yâd; horı -yâd

Koryat $=$ kor -yâd

Koryat $=$ kara $=$ yâd $<$ kor $-\mathrm{a}-\mathrm{k}$

Hor $=$ worthless,

Hor $1=$ idle, trifler

Kor $=$ small piece of burning coal or wool Kora (koruk) $=$ unripe grape

Ziyad Akkoyunlu (1992) claims that the word "horyat" was turned into "hoyrat" because of the "r $\geq y$ " and " $r \geq p$ " changes among the community similar to changes of "avrat" into "arvat", and "yaprak" into "yar pag". "hor" is "hoy" while the rest "yad" means memory. We are going to discuss his prove of his theory in details. In one of his articles in Journal of National Folklor, Akkoyunlu (1992) tried to prove that the original word for "hoyrat" is "horyat" with four explanations. The first one is about metathesis in Kirkuk accent of Turkish and the change in "horyat" as "hoyrat". It is the change we exemplified above within some letters. To make it more understandable we need to add that there are two common branches of Iraqi Turkmen accent; group "v" accent and group "y" accent. Examples for "v" group can be

“eliviz: eliniz",

"gördüv: gördün" and

"baxsaviz: baksanız".

In "y" group, some changes are also seen such as

"bacıyız: bacınız", "aldıy: aldın", and "seniy: senin". 
The second explanation is that when the root is considered as "hoy" to be a reflection and similarity between "hoyrat" and "koyrat" is considered, it is not the same with "koyrat" when analyzed with its structural construction. The third one explains that when it is considered to have a conjugate structure, the second part "yad" means "remember". "Hor" is worthless, low, simple but "hoy" doesn't have a such meaning. The lack of a meaningful root as "hoy" also shows that the original word is "horyat". His forth explanation is different from the above analyses. There is a neighborhood called "Korya" in Kirkuk where Turkmens are dominant. The songs sang in this neighborhood are called "korya" as well. Thus the possibility that the origins of the word coming from here and changed as "koryat-horyat" is also high. Some of the people living in Kirkuk supports this approach with defining the word as "koruyad" which means remembering of bad memories. According to Nail Tan, this letter change between hoyrat and horyat is because of the metathesis in Azerbaijani Turkish as it is between "toprak" and "torpaq" (Tan, 2013; interview in Antalya). Kasim Sarikaya accepting horyat as the first oral Turkmen folk literature explains that it emerged after nomadic Turkmen tribes in Middle Asia expressed their love, fight, missing, heroism and etc. with it (Sarıkaya, 2006, p.20). In some Turkish dictionaries, hoyrat is described as a Greek word. Hoyrat comes from Greek word "hoyratis" which means rude, harsh, maltreating (Turkce Sozluk, 1998, p.1006). İbrahim Dakuklu (1970) tells the story of horyat:

the need of invention of some poems -sentences-convenient with the walk of camels and beginning of Arabic poetry and the need of invention of a kind of poetry sang by nomadic Turkic tribes were the similar. These first trials of Turkmen poetry can be accepted as the beginning. These songs were quiet simple. After the improvement of Turkmen poetry, these were called "hor şiir, kor şiir" meaning simple and worthless poem in order to differentiate old and new poetry. When these became common, the word "şiir" (poem) was neglected and "hor" or "kor" was left. Later on, they were turned into "horyat" and "koryat" with the pluralization rule of Turkish (p.98-99).

Faruk Sumer claims that "horyat" is produced from "Oyrat" the name of one of the Mongol tribes settled into Iraq in 14th century (cited in Terzibaş1,1975, p.51). In his introduction of the book "Kerkuk Horyats", Osman Mazlum quoted from Hicri Dede about the origin of horyat: "It is not yet certain why this type was called "horyat" in our literature. Once some of the teenagers belonging to an old Christian family called "Hori" living in the castle were singing some poems by walking drunk around the city at night. This situation not reproved became common around and these poems were called "horyat" after the name of this Christian family. People in Kirkuk still call the people who are drunk and walking in the streets naughty and unmannerly as "hori" (Mazlum, 1975, p.3). According to Ata Terzibasi, "hoyrat" is a word used for toughness and belligerency. He explained the birth and spread of horyat in the Journal of Kardaslik. He thinks that horyat is the one of the best types of folk literature. According to him, this type of literature was born among the Turkmens lived in Iraq in ancient times and was improved in literary and musical way during the reign of Akkoyunlu, Karakoyunlu and Seljuk Turkish states and transferred to Ottoman state. Horyat born in Iraq spread to Turkey, Tebriz and Azerbaijan (Terzibasi, 2013: interview in Kirkuk). He claims that horyat with its numerous functions and meanings was first born in Turkmen tribe of Bayat and spread towards other regions. According to him, the reason for common use of the name "bayat" can be understood when it is considered that this tribe adopted the horyat the most. For example: 
"Çağırdım bayat bayat

Zülfüy üzüyden yanat

Oyadiram oyanmaz

Yatarsay ha yat ha yat" (Anonymous)

People in Azerbaijan name horyat as "bayati". Thus, Muhammed Bayat and some others base horyat to Bayat tribe. Memmedov also connects "bayati" to Bayat tribe (Memmedov,1988, p.6). Bayat tribe began settling in Azerbaijan at the end of 16th century. Karaagac (1998) also cited from Faruk Sumer that bayati was common orally among Bayat community when they were a nomadic tribe and became written when they settled. In Turkey, horyat is not widespread and known as legged mani (ayaklı mani). The reason for its widespread in Azerbaijan is that both nations came from Oghuz tribe and have similar dialects. There are some other approaches to the origins of horyat. One of these is Ali Marufoglu's approach. He claims that horyat is the equivalence of "heyriyyat" used by common people. The origins of this word come from the death ceremonies of Shiite Turkmens since old times according to Marufoglu. They are telling verses during the charity for the deaths on the 40th day of their loses. Thus, Marufoglu claims, the original "heyriyyat" was turned into "horyat" in time. He is also arguing that the reason for naming horyat as bayati in Azerbaijan is from the same reason. The term bayati was emerged as a result of ceremonies for the 40th day of death in Bayati tribe (Marufoğlu, 2013; interview in Kirkuk-Tuzhurmatu). When we consider different usages and etymological explanations, the use of "horyat or horyat" variations are in the center of all approaches. When we consider all the approaches, the use of the word in Kirkuk and Ziyad Akkoyunlu's description, we strongly agree with the horyat as the origin of the word.

\section{Conclusion}

To sum up we can say that horyats were named and defined in various ways as it is to some other literary types. There are different stories about history and origin of them as well although none of them are certain. As a result of the explanations in this article, it seems that the term "horyat" is in the center of approaches. People, who are interested in this literary type intensively such as Ata Terzibasi and his followers, used the term as "horyat". "Hoyrat" can be neglected because of its unsuitability to a highly valued literary type of Iraqi Turkmens with its meaning as "poor, indigent and idle".

\section{References}

Akkoyunlu, Z. (1992). Kerkük ağzı'nda mani ve hoyrat'a dair. Milli Folklor Dergisi, 14, 2-6. Ayverdi, İ. (2008). Asırlar boyu tarihi seyri içinde misalli büyük Türkçe çağbayır, In Yaşar, (2007) Orhun yazıtlarından günümüze Türkiye Türkçesinin söz varlığı. Ötüken Yayınları, İstanbul.

Dakuklu, İ. (1970). Irak Türkleri diller tarihi ve edebiyat. Ankar: Guven Yayinlari.

Ercilasun, A. (1991). Karşılaştırmalı Türk lehçeleri sözlüğü. Ankara: Kültür Bakanlığı Yayınlari.

Karaağaç, G., \& Açikgöz, H. (1998). Azerbaycan bayatıları, Ankara: Atatürk Kültür, Dil ve Tarih Yüksek Kurumu Yayınları.

Köse, N. (2003). Türk düğünlerinde gerdek sonrası duvak geleneği. Milli Folklor Dergisi, 60. Feryal Matbaası Ankara.

Mazlum, O. (1975). Hoyratlar. Bağdad. Kultur Yayinlari Dizisi.

Memmedov, E. (Tertip eden), (1988). Azerbaycan edebiyatı incileri (Bayatı-Goşma-Tecnis). Baku: Yazıçı Neşriyyat.

Paşayev, G. (1987). Kerkük folklor antologiyası. Baku: Azerneşr, 
Saatçi, S. (2007). Tarihten günümüze Irak Türkmenleri. Ankara: Ötüken Neşriyat.

Sarıkaya, K. (2006). Irak Türkmen edebiyatı'nda hoyratlar. Ankara: Irak Türkmen Cephesi Kültür Müdürlüğü Yayınları.

Terzibaşı, A. (1975). Kerkük hoyratları ve manileri. Istanbul: Ötüken Yayınlari.

Türk Dil Kurumu (1998). Türkçe sözlük. Ankara: Türk Tarih Kurumu Basımevi. 